\title{
PERIPHERAL PLASMA PROGESTIN LEVELS DURING ANOESTRUS, OESTRUS AND PSEUDOPREGNANCY AND FOLLOWING HYPOPHYSECTOMY IN FERRETS
}

\author{
F. R. BLATCHLEY AND B. T. DONOVAN \\ Department of Physiology, Institute of Psychiatry, Denmark Hill, London SE5 $8 A F$
}

(Received 24th May 1972, accepted 7th July 1972)

The changes in luteal function during pregnancy and pseudopregnancy in the ferret have previously been assessed by the study of the morphology of the ovaries and uterine tract (Hammond \& Marshall, 1930; Donovan, 1967) but, with the development of competitive protein-binding techniques, the measurement of progesterone in small quantities of blood has become possible. We have used this procedure to assess progestin secretion by ovarian tissue in anoestrous, oestrous and pseudopregnant ferrets, and also after hypophysectomy.

Blood samples $(2 \mathrm{ml})$, withdrawn by cardiac puncture under Nembutal anaesthesia, were centrifuged as soon as possible after collection and the plasma was stored at $-20^{\circ} \mathrm{C}$ until assay. Plasma progestin concentrations were measured in $0 \cdot 1-\mathrm{ml}$ aliquots in triplicate as described previously (Blatchley, Donovan, Horton \& Poyser, 1972), the limit of sensitivity being $0.8 \mathrm{ng} / \mathrm{ml}$.

Ten anoestrous and six oestrous ferrets were used to determine the progestin content of the blood in these reproductive states. Twenty oestrous ferrets were made pseudopregnant by the subcutaneous injection of $300 \mu \mathrm{g} \mathrm{LH}$ (LH.NIH.B4) and killed at various intervals throughout the ensuing 6 -week period. At autopsy, a blood sample was collected and the ovaries were weighed and fixed for histological processing. Luteal size was estimated from histological sections by measuring two diameters at right angles across the largest section of four CL in each ovary, the size being expressed as the mean diameter in $\mathrm{mm}$. Pseudopregnancy was induced in a further nine oestrous ferrets and again blood was withdrawn by cardiac puncture under Nembutal anaesthesia at various intervals subsequently. Not more than four samples were provided by one ferret over the 6-week period.

Six ferrets were hypophysectomized on Day 7 of pseudopregnancy by the parapharyngeal route under Nembutal anaesthesia after a blood sample had been obtained. One animal died soon after the operation and another after cardiac puncture on Day 14 but the others survived well. Blood samples were withdrawn at weekly intervals until autopsy on Day 21, when the head and ovaries were collected. The completeness of the hypophysectomy procedure was checked histologically. The ovaries of one female were abnormal in containing large fibrous growths and this animal was therefore discarded.

The concentrations of progestin in anoestrous and oestrous ferrets were below the measurable level, i.e. less than $0.8 \mathrm{ng} / \mathrm{ml}$. The data obtained throughout 
pseudopregnancy are presented in Table 1. Luteal size increased steadily until Day 14 and from this stage to about Day 28 , a plateau level of about $2.0 \mathrm{~mm}$ was reached. Between Days 28 and 42, a slight decrease in luteal size occurred. A rise in peripheral plasma progestin levels matched the increase in luteal size up to Day 14, and was maximal at $17.7 \mathrm{ng} / \mathrm{ml}$ on Day 21 . Thereafter, the levels declined fairly rapidly and, by Day 35 , they were only about $4.0 \mathrm{ng} / \mathrm{ml}$. Removal of the pituitary on Day 7 of pseudopregnancy caused a rapid decline in progestin concentration (Table 1). At autopsy on Day 21, hormone levels were very low; histologically, the luteal bodies, although well formed, contained small lutein cells with little cytoplasm and shrunken nuclei, and were markedly different from the large lutein cells characteristic of Day 21 of normal pseudopregnancy. No antral follicles were present in the ovaries.

\section{TABLE 1}

PLASMA PROGESTIN GONGENTRATION AND GL SIZE IN THE FERRET DURING VARIOUS NON-PREGNANT REPRODUGTIVE STATES AND FOLLOWING HYPOPHYSECTOMY ON DAY 7 OF PSEUDOPREGNANCY

\begin{tabular}{|c|c|c|c|}
\hline Day of pseudopregnancy & $\begin{array}{l}\text { No. of } \\
\text { animals }\end{array}$ & $\begin{array}{c}C L \text { size }(\mathrm{mm}) \\
\text { Mean } \pm \text { S.E.M. }\end{array}$ & $\begin{array}{c}\text { Plasma progestin } \\
\text { conc. }(\mathrm{ng} / \mathrm{ml}) \\
\text { Mean } \pm \text { S.E.M. }\end{array}$ \\
\hline $\begin{array}{l}\text { Anoestrous } \\
\text { Oestrous }\end{array}$ & $\begin{array}{r}10 \\
6\end{array}$ & - & $\begin{array}{l}<0.8 \\
<0.8\end{array}$ \\
\hline \multicolumn{4}{|l|}{ Normal } \\
\hline Day 7 & $6(4)$ & $1.5 \pm 0.06$ & $7 \cdot 27 \pm 0.7$ \\
\hline Day 14 & $6(4)$ & $2 \cdot 0 \pm 0.03$ & $15 \cdot 76 \pm 3 \cdot 5$ \\
\hline Day 21 & $7(4)$ & $2 \cdot 0 \pm 0.04$ & $17 \cdot 7 \pm 2 \cdot 1$ \\
\hline Day 28 & $7(3)$ & $2 \cdot 0 \pm 0 \cdot 07$ & $10 \cdot 22 \pm 2 \cdot 4$ \\
\hline Day 35 & $5(3)$ & $1 \cdot 8 \pm 0.06$ & $3.8 \pm 0.55$ \\
\hline Day 42 & $5(2)$ & $1.7 \pm 0.07$ & $2 \cdot 72 \pm 0 \cdot 4$ \\
\hline After hypophysectomy & & & \\
\hline Day 7 & 5 & 一 & $12 \cdot 39 \pm 1.56$ \\
\hline Day 14 & 4 & - & $1.71 \pm 0.15$ \\
\hline Day 21 & 3 & - & $<\overline{0} \cdot 8$ \\
\hline
\end{tabular}

Numbers in parentheses indicate the number of animals which contributed to luteal size data.

These results demonstrate the need of pituitary support for continued progestin secretion by luteal cells. The decreasing levels of progestin in late pseudopregnancy in the absence of marked changes in luteal size imply that structural and functional luteolysis are not coincident. Histologically, there is no evidence of uterine involvement in luteal degeneration in this species (Deanesly \& Parkes, 1933), while prostaglandin $\mathrm{F}_{2 \alpha}$, injected in quantities known to be lytic in the guinea-pig, does not hasten morphological regression of the CL or depress progestin secretion (unpublished data). The finding that there is negligible progestin secretion by the anoestrous, as well as the oestrous, ferret ovary is at variance with the results of Carlson \& Rust (1969).

We wish to thank Mrs Maureen Harrison for the histological preparations and the Population Council for financial support. 


\section{REFERENCES}

Blatchley, F. R., Donovan, B. T., Horton, E. W. \& Poyser, N. L. (1972) The release of prostaglandins and progestin into the utero-ovarian venous blood of guinea-pigs during the oestrous cycle and following oestrogen treatment. F. Physiol., Lond. 222, 69.

CARLson, I. H. \& Rust, C. C. (1969) Plasma progesterone levels in pregnant, pseudopregnant and anestrous ferrets. Endocrinology, 85, 623.

Deanesly, R. \& Parkes, A. S. (1933) The effect of hysterectomy on the oestrous cycle of the ferret. $\mathcal{F}$. Physiol., Lond. 78, 80.

Donovan, B. T. (1967) The control of corpus luteum function in the ferret. Archs Anat. microsc. Morph. exp. 56, (Suppl. 3-4), 315.

Hammond, J. \& Marshall, F. H. A. (1930) Oestrus and pseudopregnancy in the ferret. Proc. R. Soc. B, $105,607$. 